\title{
Mentale Stärke - eine gute Idee!
}

\author{
Wie sich Schüler ändern, wenn sie lernen, dass das Gehirn „wie ein Muskel“ \\ funktioniert
}

Korrespondenzadresse

Prof. Dr. Dr. Manfred Spitzer

Universität Ulm

Abteilung für Psychiatrie

Leimgrubenweg 12-14

87054 Ulm
Bibliografie

DOI https://doi.org/10.1055/a-0952-7310

Nervenheilkunde 2019; 38: 882-886

(c) Georg Thieme Verlag KG Stuttgart · New York

ISSN 0722-1541
Es kommt nicht oft vor, dass im Fachblatt Nature eine Studie aus der Pädagogik als Research Article (also im dort größten Format und nicht einfach nur als kürzerer Letter) publiziert wird. Daher ist es umso bemerkenswerter, wenn dies geschieht, zumal $25 \mathrm{Au}$ toren aus 15 Universitäten über einen ganz einfachen Sachverhalt scheiben, der schon lange bekannt ist: Die eigene Einstellung zum Thema Begabung und Anstrengung hat eine Auswirkung auf das Lernverhalten von Schülern: Wer glaubt „das ist alles Begabung - da kann man eh nichts machen“, der macht auch nichts. Und wer glaubt „es hängt vom Training ab, wie gut ich werde“, der trainiert. In den meisten Gesellschaften Ostasiens beispielsweise sind die Schüler davon überzeugt, dass derjenige, der viel lernt, gut in Mathematik sein wird [14]. In Deutschland hingegen glauben die Schüler, dass man für Mathematik begabt sein muss und dass Lernen daher nichts bringt. Entsprechend sind die Leistungen der Schüler im Fach Mathematik nach internationalen Vergleichsstudien in Ostasien wesentlich besser als hierzulande.

Wie groß ist der Effekt der inneren Einstellung am Schulerfolg? Und, wichtiger noch, kann man die innere Einstellung und damit den Schulerfolg ändern? Ein in den USA durchgeführtes Experiment mit über 12000 Schülern im Alter von 14 bis 15 Jahren aus einem national repräsentativen Sample von Schulen (high schools) ergab hierzu bemerkenswerte Antworten: Der Effekt der inneren Einstellung auf den Schulerfolg ist vergleichsweise groß und man kann die innere Einstellung von Schülern durch eine Maßnahme ändern, die fast nichts kostet und nur etwa 50 Minuten dauert.

Aufbauend auf einer früheren ähnlichen Studie [16] hatten Schüler am Anfang der 9. Klasse Gelegenheit, sich am Computer eine Präsentation anzusehen (selbstgesteuert), in der ihnen erklärt wird, dass das Gehirn ganz ähnlich wie ein Muskel funktioniert. Es wächst mit seiner Benutzung, wie Erkenntnisse aus der Gehirnforschung zum Thema Neuroplastizität zeigen. Seit einigen Jahren wird diese Denkweise bzw. Haltung oder innere Einstellung als „Growth Mindset“ bezeichnet, dessen Auswirkungen auf die Motivation und den Lernerfolg untersucht wurden. Dass die innere Einstellung des Lernenden einen großen Unterschied machen kann, war schon vor 10 Jahren in der Nervenheilkunde Thema [13]. Und dass die Neurowissenschaften die Grundlage von Lernprozessen heute besser verstanden haben als man dies noch vor wenigen
Jahrzehnten für möglich gehalten hätte, bestimmt nicht nur unser Denken über Psychiatrie und Schule wesentlich [11, 12], sondern ist auch das Geschäftsmodell der wertvollsten Firmen der Welt: Amazon, Microsoft. Alphabet (Google), Apple, Facebook, Tencent, Alibab ${ }^{1}$ sowie - etwas abgeschlagen - Intel und IBM. ${ }^{2}$ Wir haben also allen Grund, diese Gedanken ernst zu nehmen.

Dass ein solches Wissen um Neuroplastizität im Allgemeinen, und die Veränderbarkeit der geistigen Leistungsfähigkeit des Menschen durch Lernen im Besonderen, direkt das Lernen beeinflussen kann, wird erst seit einem guten Jahrzehnt systematisch erforscht $[4,5,15,18,19]$. Man kontrastiert hierzu oft ein „Fixed Mindset“, das (vermeintlich angeborene) Begabung oder Intelligenz für bedeutsam beim Lernen hält, mit einem „Growth Mindset“, das die Möglichkeiten zur Veränderung in den Vordergrund stellt. Wenn Schüler und Studenten davon überzeugt sind, dass man an Herausforderungen wachsen kann, weil das Gehirn sich ändern kann und dies auch permanent tut - es lernt eben -, dann sind sie eher dazu in der Lage, diese Herausforderungen auch tatsächlich zu meistern. Sie weisen beim Lernen eine höhere Motivation und eine größere Frustrationstoleranz auf, was man auch als höhere Resilienz zusammenfasst - so das Argument von Wissenschaftlern wie David Yaeger von der University of Texas in Austin und von Carol Dweck von der Stanford University in Kalifornien [15]:

„Während sie unser Bildungssystem durchlaufen, haben alle Schüler irgendwann Probleme im sozialen oder akademischen Bereich. Daher gehört es zu den zentralen Aufgaben von Eltern und Erziehern, sie darauf vorzubereiten, sodass sie auf diese unvermeidlichen Herausforderungen standhaft reagieren können. Obwohl Eltern und Erzieher hierbei intuitive Strategien verfolgen, sind viele dieser Strategien möglicherweise ungeeignet, wie beispielsweise die Strategie, den Schülern zu sagen, dass sie schlau seien, um ihr Selbstwertgefühl zu stärken, oder die Strategie, aggressive Schüler als Bösewichte zu verdammen. [...] Wir haben herausgefun-

1 Tencent und Alibaba sind die größten chinesischen Internetfirmen.

2 Es gibt hierzu im Netz eine Reihe von Quellen. Die hier verwendete Reihenfolge bzw. Nummerierung ist dem Börsenportal von Focus online „Finanzen 100“ entnommen. www.finanzen100.de/top 100/die-grossten-borsennotierten-unternehmen-der-welt/; abgerufen am 5.10.2019. 
den, dass Schüler weder übertriebenes Selbstvertrauen, noch die Brandmarkung im Hinblick auf bestimmte Persönlichkeitseigenschaften für ihren Erfolg brauchen, sondern Geisteshaltungen, die Probleme als etwas betrachten, was man angehen und überwinden kann - mit Zeit, Anstrengung, neuen Strategien, Lernen, Hilfe von anderen und Geduld. Wenn wir hervorheben, dass die Leute Potenzial für Veränderung haben, bereiten wir unsere Schüler darauf vor, auf die Probleme, die ihnen das Leben bringt, stark und gesund zu reagieren “ 3 [15].

In der neuen Studie - „The National Study of Learning Mindsets “ - wurde die Effektivität einer kurzen am Computer stattfindenden Online-Intervention in einer für die USA repräsentativen Stichprobe von 6320 Neuntklässlern mit unterdurchschnittlichen Leistungen aus regulären öffentlichen Schulen untersucht. Man legte großen Wert auf methodische Details wie Repräsentativität der Stichprobe, Randomisierung, Verblindung der Beteiligten und Verblindung bei der Analyse der Daten sowie vorher festgelegten Hypothesen und Auswerteroutinen. Die Studie wurde vor Beginn registriert (pre-registered study) und danach wie beschrieben durchgeführt. ${ }^{4}$ Die Schulen wurden nach dem Anteil von Minderheiten sowie dem Schulerfolg („level of achievement“) stratifiziert. Zur Teilnahme wurden Schüler ausgewählt, die im Vergleich zu ihren Schulkameraden an der jeweiligen Schule unterdurchschnittliche Schulleistungen aufwiesen. Man zielte mit der Intervention also auf die Gruppe der in akademischer Hinsicht schwächeren („lower-achiving“) Schüler ab.

In die Studie wurden 12640 Schüler aus 65 Schulen aufgenommen und einzeln in 2 Gruppen randomisiert. Die eine $(n=6320)$ er-

3 „As students move through our educational system, all of them will face adversity at one time or another, whether it is social or academic in nature. Thus, a central task for parents and educators is to prepare students to respond resiliently when these inevitable challenges arise. Although educators and parents have intuitive strategies for doing so, many of these strategies may be ill-advised, such as praising students for being "smart" to boost their self-esteem or condemning those who behave aggressively as evil bullies. [...] We have found that what students need the most is not self-esteem boosting or trait labeling; instead, they need mindsets that represent challenges as things that they can take on and overcome over time with effort, new strategies, learning, help from others, and patience. When we emphasize people's potential to change, we prepare our students to face life's challenges resiliently."

$4 \quad$ Wie bei vielen wissenschaftlichen Arbeiten üblich, ist der (nur online publizierte) Methodenteil der Arbeit deutlich länger als die 6-seitige Druckversion. Um dem Leser einen Eindruck vom methodischen Aufwand zu geben, sei aus dem Abschnitt Data collection im Methodenteil etwas ausführlicher zitiert. „To ensure that the study procedures were repeatable by third parties and therefore scalable, and to increase the independence of the results, two different professional research companies, who were not involved in developing the materials or study hypotheses, were contracted. One company (ICF) drew the sample, recruited schools, arranged for treatment delivery, supervised and implemented the data collection protocol, obtained administrative data, and cleaned and merged data. They did this work blind to the treatment conditions of the students. This company worked in concert with a technology vendor (PERTS), which delivered the intervention, executed random assignment, tracked student response rates, scheduled makeup sessions and kept all parties blind to condition assignment. A second professional research company (MDRC) processed the data merged by ICF and produced an analytic grades file, blind to the consequences of their decisions for the estimated treatment effects [...]. Those data were shared with the authors of this paper, who analysed the data following a pre-registered analysis plan“ [18]. hielt die „Growth-Mindset-Intervention“, die andere eine („Fixed Mindset“) Kontrollintervention, in der Wissen über das Gehirn vermittelt wurde, jedoch keinerlei explizite Konsequenzen aus diesem Wissen für die Lernhaltung, d. h. die Einstellungen zur Möglichkeit von Veränderung, gezogen wurden ( $\triangleright$ Abb. 1). Das Growth Mindset (wörtlich aus dem Englischen „Wachstumseinstellung“) beschreiben die Autoren wie folgt:

„Die Wachstumseinstellung-Intervention zielte darauf ab, die negativen Überzeugungen der Schüler im Hinblick auf Anstrengung zu reduzieren, also

- die Auffassung, dass man unbegabt sei, wenn man sich anstrengen oder um Hilfe bitten muss,

- die Auffassung, dass mangelnde Leistung auf geringere Begabung beruht („fixed-trait attributions“, zu Deutsch, Begabungszuschreibung [des eigenen Unvermögens]) und

- die Vermeidung von Leistung, damit man vor anderen nicht dumm erscheint [d. h. damit es nicht auffällt, wie wenig man tatsächlich kann].

Diese Überzeugungen zu den Auswirkungen und zur Unveränderbarkeit der eigenen Begabung („Fixed Mindset“) haben erwiesenermaßen einen ungünstigen Einfluss auf die Schulnoten, und die Intervention „Wachstumseinstellung“ soll diesen negativen Einfluss vermindern. Die Intervention „Wachstumseinstellung“ widersprach nicht nur diesen [ungünstigen] Überzeugungen, sondern verwendete auch eine Reihe von interessanten praktischen Übungen, welche die Glaubwürdigkeit [des Fixed Mindset] verminderten “5 [17].

Vier Wochen nach der Intervention, die im Mittel 25 Minuten dauerte, wurde diese nochmals wiederholt, und gleich danach wurde ihr Effekt auf die Reduktion des Fixed Mindset erhoben. Nach dem Ende des 9. Schuljahres wurden dann die Noten (Gesamtdurchschnitt sowie einzeln in den Fächern Mathematik, Naturwissenschaften, Englisch und Sozialwissenschaften, d. h. „Gemeinschaftskunde“) erfasst und ausgewertet. Das Ergebnis der Studie war, dass die Intervention wirkte, d. h. den Glauben an eine feste Begabung oder Intelligenz reduzierte. Im Vergleich zur Kontrollgruppe wurde eine signifikante $(p<0,001)$ Reduktion $(B=-0,38)$ dieser Auffassung vom (genetischen) Festliegen der Begabung gefunden, die Effektstärke betrug 0,33, d. h. ein Drittel der Standardabweichung des Mittelwerts. ${ }^{6}$ Dies wiederum wirkte sich positiv auf die Schulnoten aus, die in der Interventionsgruppe signi-

5 "The growth mindset intervention aimed to reduce the negative effort beliefs of students (the belief that having to try hard or ask for help means you lack ability), fixed-trait attributions (the attribution that failure stems from low ability) and performance avoidance goals (the goal of never looking stupid). These are the documented mediators of the negative effect of a fixed mindset on grades and the growth mindset intervention aims to reduce them. The intervention did not only contradict these beliefs but also used a series of interesting and guided exercises to reduce their credibility."

6 Es gibt unterschiedliche Maße für die Stärke eines Effekts. Letztlich wird damit versucht, die Variationsbreite einer Variablen in die Beurteilung einer Abweichung vom Mittelwert einzubeziehen. Das hier verwendete Maß entspricht letztlich dem vom Intelligenzquotienten her bekannten $\mathrm{Maß}$, bei dem der Mittelwert mit 100 und eine Standardabweichung mit 15 festgelegt werden. Eine Effektstärke von 0,2 entspräche damit 3 IQ-Punkten. 


\title{
Stronger Connections Make a Smarter Brain
}

\author{
The connections between neurons can be weak or \\ strong. When you work hard to learn something \\ new-like a new type of math problem-the \\ connections in your brain get stronger.
}

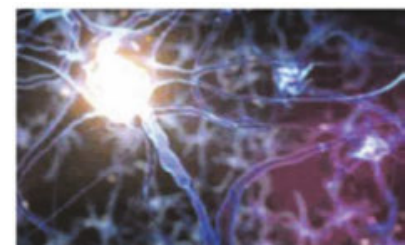

The brain's connections also get stronger when you practice basic skills. Over time, these stronger connections can make you smarter in a subject.

\section{The Teenage Brain Can Become Much Stronger-If You Know How to Make It Happen}

\begin{abstract}
Let's think about this some more. The brain can get stronger at any age, but there are two times in life when the brain is especially ready to grow. The first is when you are a baby or a very young child. The second is when you're a teenager.
\end{abstract}

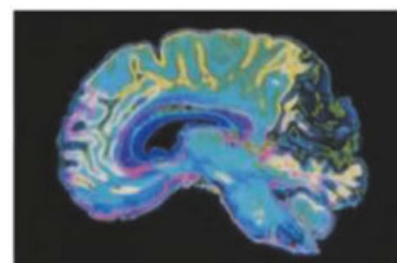

As you know, teenage hormones do a lot of different things. But you might not know that hormones get your brain ready to learn and get stronger. They prepare the brain to grow when it's challenged. That's why the high school years are a special time when you can grow your intelligence.

- Abb. 1 Beispiele (Screenshots) aus der bildschirmgestützten Intervention (nach Daten aus [17]).

fikant $(p<0,001)$ besser waren als in der Kontrollgruppe $(B=0,10$; Effektstärke 0,11).

Zur besseren Einordnung ihrer Ergebnisse vergleichen Yeager und Mitarbeiter die Effektstärken mit denen aus anderen Untersuchungen ( $\triangleright$ Abb. 2) [17]. Wie die Autoren ausführen, entspricht eine Effektstärke von 0,2 den Auswirkungen von einem Schuljahr (in der Mittelstufe) auf Testergebnisse in standardisierten Schulleistungstests [7]. Auch liegt diese Effektstärke am oberen Rand der in Studien gefundenen Auswirkungen eines sehr guten Lehrers (im Vergleich zu einem durchschnittlichen Lehrer) auf die Schulleistungen innerhalb eines Jahres [6] und sie liegt am oberen Ende der Verteilung von Effektstärken, die bei verschiedenen Interventionsstudien „in der wirklichen Welt“ gefunden wurden. Der Mittelwert der Effektstärken aus diesen Studien betrug 0,03 Standardabweichungen [17].

Die Studie war so angelegt, dass man nicht nur den Effekt der Intervention klar herausarbeiten konnte, sondern vor allem auch die Quellen von dessen Varianz: Bei wem und unter welchen Bedingungen wirkt die Intervention besonders gut?

Zum einen zeigte sich, dass die Intervention stärker wirkt, wenn die Wachstumseinstellung zu den in der Schule vorherrschenden Werten und Normen passt. In Schulen, in denen die Schüler da- gegen eher zum „Fixed Mindset“ neigen, wirkt die Intervention weniger. „[...] die Intervention zeigte nach dem Ende des Schuljahres einen größeren Effekt auf die Durchschnittsnoten der unterdurchschnittlichen Schüler, wenn die sie umgebende Verhaltensnorm die Wachstumseinstellung unterstützte “7 [17]. Zudem zeigte die Auswertung, dass bei guten Schulen der Effekt geringer war als bei weniger guten. Dies interpretieren die Autoren dahingehend, dass diese Schulen schon entsprechende Ressourcen bei den Schülern aktivieren, also diese letztlich besser zum Lernen motivieren, und daher bei ihnen weniger Luft nach oben besteht als bei den eher schwachen Schulen. Schließlich wurden ja ohnehin schwache Schüler untersucht, bei denen definitionsgemäß mehr Luft nach oben besteht.

Untersucht wurde weiterhin noch der Einfluss der Intervention auf die Belegung von anspruchsvolleren („advanced“) Mathematikkursen in der 10. Klasse (also fast ein Jahr nach der Intervention). In der Interventionsgruppe wurden von 36\% der Schüler diese Kurse belegt, in der Kontrollgruppe von 33 \%. Der Unterschied von

$7 \quad[\ldots]$ the intervention produced a greater difference in end-of-year GPAs relative to the control group when the behavioural norm that surrounded students was supportive of the growth mindset belief system.“ 


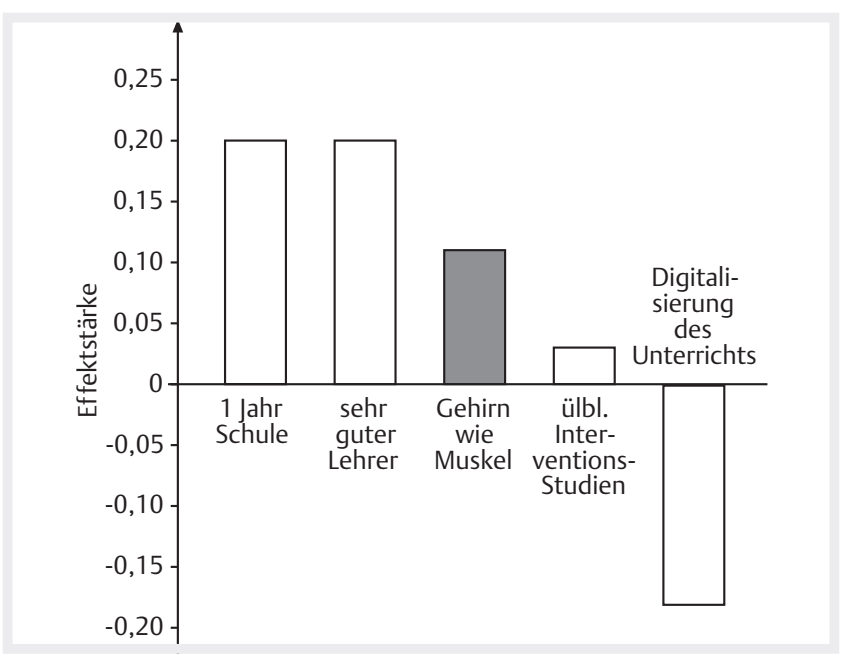

- Abb. 2 Vergleich der Effektstärken von Interventionen auf die Schulnoten aus verschiedenen Studien. Ein Jahr Beschulung mit gutem Unterricht bringt in der Mittelstufe eine deutliche Verbesserung in entsprechenden Leistungstests [7], ein sehr guter Lehrer hat etwa den gleichen Effekt [6]. Verschiedene Interventionen aus "der wirklichen Welt“ bringen im Mittel nicht sehr viel [17]. Eine Studie zu den Auswirkungen der Einführung von Laptops und Tabletts an der Militärakademie von Westpoint ergab eine deutliche Verschlechterung ( 0,18 Standardabweichung) der Leistungen. Abbildung von MS nach [17] und [3].

absolut $3 \%$ bzw. relativ $9 \%$ war nicht nur (mit p $=0,001$ ) hoch signifikant, er war vor allem in den $25 \%$ besten Schulen mit $4 \%$ höher ausgeprägt als mit $2 \%$ in den $75 \%$ schwächeren Schulen. Obgleich also der Effekt auf die Noten in den besseren Schulen geringer war (weniger Luft nach oben bei den Noten), waren die Auswirkungen im Hinblick auf die weitere Bildungskarriere - Mathematikkenntnisse prädizieren weiteren Erfolg (von allen Fächern vergleichsweise) am besten - auch und gerade bei den Schülern in guten Schulen durchaus messbar.

Die Autoren diskutieren abschließend ihre Ergebnisse wie folgt: „Der Befund, dass die Wachstumseinstellungs-Intervention einen derartig großen Einfluss auf die akademische Laufbahn eines Schülers haben kann - ohne Fortbildung der Lehrer; in einer Wirksamkeitsstudie, mit einer Stichprobe, die für die gesamte Population der Schüler repräsentativ ist; mit Daten, die von einer unabhängigen Forschungseinrichtung mit wiederholbaren Verfahren gesammelt wurden; mit Daten die von einer zweiten unabhängigen Forschungseinrichtung verarbeitet wurden; wobei insgesamt einem vorher spezifizierten Forschungs- und Datenanalyseplan gefolgt wurde - stellt einen wesentlichen Fortschritt dar"8 [17].

Nach einer Studie der Caritas lag im Jahr 2017 die Zahl der Schulabbrecher in Deutschland bei mehr als 52 000, was einem Anteil von $6,9 \%$ aller Schüler entspricht. Die regionalen Unterschiede sind

8 „The finding that the growth mindset intervention could redirect critical academic outcomes to such an extent-with no training of teachers; in an effectiveness trial conducted in a population-generalizable sample; with data collected by an independent research company using repeatable procedures; with data processed by a second independent research company; and while adhering to a comprehensive pre-registered analysis plan-is a major advance.“ erheblich mit Berlin an der traurigen Spitze (knapp $12 \%$ aller Schüler) und Bayern (6,00\%), Hamburg (5,97\%) und Hessen (5,42\%) eher im grünen Bereich. Berücksichtigt man, dass diese Schüler hierdurch zeitlebens im Hinblick auf Gesundheit und Wohlbefinden beeinträchtigt sein können [10], erscheint eine Intervention, die (nahezu) nichts kostet und 50 Minuten dauert, fast zu gut und zu wirksam, um überhaupt wahr zu sein. Man sollte sie daher unbedingt im Rahmen des deutschen Bildungssystems replizieren und den entsprechenden Aufwand treiben. Dies nicht zu tun, wäre unverantwortlich und liefe auf eine mögliche Verschwendung von Ressourcen in großem Stil hinaus.

\section{Literatur}

[1] Benartzi $S$ et al. Should governments invest more in nudging? Psychol Sci 2017; 28: 1041-1055

[2] Boulay B et al. The Investing in Innovation Fund: Summary of 67 Evaluations (US Department of Education) 2018

[3] Carter SP, et al. The impact of computer usage on academic performance: Evidence from a randomized trial at the United States Military Academy. Economics of Education Review 2017; 56: 118-132

[4] Claro S, Paunesku D, Dweck CS. Growth mindset tempers the effects of poverty on academic achievement. PNAS 2016; 113: 8664-8668

[5] Costa A, Faria L. Implicit Theories of Intelligence and Academic Achievement: A Meta-Analytic Review. Front Psychol 2018; 9: 829. doi:10.3389/fpsyg.2018.00829. eCollection 2018

[6] Hanushek E. Valuing teachers: how much is a good teacher worth? Educ Next 2011; 11: 40-45

[7] Hill C], Bloom HS, Black AR et al. Empirical benchmarks for interpreting effect sizes in research. Child Dev Perspect 2008; 2: 172-177

[8] Kraft M. Interpreting Effect Sizes of Education Interventions. Im Internet: https://scholar. harvard.edu/files/mkraft/files/kraft_2018_interpreting_effect_sizes.pdf (Brown University);

[9] Martin A, et al. Physical activity, diet and other behavioural interventions for improving cognition and school achievement in children and adolescents with obesity or overweight. Cochrane Database Syst Rev 2018; 3: CD009728. doi:10.1002/14651858.CD009728.pub4

[10] Patton GC, et al. Our future: a Lancet commission on adolescent health and wellbeing. Lancet 2016; 387: 2423-2478

[11] Spitzer M. Geist im Netz. Heidelberg: Spektrum; 2016

[12] Spitzer M. Lernen. Heidelberg: Spektrum; 2003

[13] Spitzer M. Ja, ich kann! Selbstbild, Selbstbejahung und nachhaltige Leistungsfähigkeit. Nervenheilkunde 2009; 28: 425-430

[14] Trumpa S, Wittek D, Sliwka A. Die Bildungssysteme der erfolgreichsten PISA-Länder China, Finnland, Japan, Kanada und Südkorea. Münster: Waxmann; 2017

[15] Yeager DS, Dweck CS. Mindsets that promote resilience: When students believe that personal characteristics can be developed. Educational Psychologist 2012; 47: 302-314

[16] Yeager DS, et al. Using design thinking to improve psychological interventions: the case of the growth mindset during the transition to high school. J Educ Psychol 2016; 108: 374-391

[17] Yeager DS, et al. A national experiment reveals where a growth mindset improves achievement. Nature 2019; 573: 364-369

[18] Dweck CS, Yeager DS. Mindsets: A view from two eras. Perspectives on Psychological science 2019; 14: 481-496

[19] Walton GM, Wilson TD. Wise Interventions: Psychological remedies for social and personal problems. Psychological Review 2018; 125: 617-655 